\title{
How successful are Turkish orthopedists in complying with time limit in scientific presentations?
}

\author{
Türk ortopedistleri bilimsel sunumlarda zaman kısıtlamasına uymada ne kadar başarılı?
}

\author{
Nadir Yalçın, MD, ${ }^{1}$ Enes Uluyardımcı, MD, ${ }^{2}$ Ibrahim Bozkurt, MD ${ }^{2}$ \\ 'Department of Orthopaedics and Traumatology, Atatürk Training and Research Hospital, Ankara, Turkey \\ ${ }^{2}$ Department of Orthopedics and Traumatology, Viranşehir State Hospital, Şanlıurfa, Turkey
}

\begin{abstract}
Objectives: This study aims to investigate the durations of scientific presentations and factors affecting the rates of exceeding the time limit in presentations at $26^{\text {th }}$ Turkish National Congress of Orthopedics and Traumatology, which is one of Turkey's largest nationally organized orthopedics and traumatology meetings in terms of the numbers of speakers and participators.
\end{abstract}

Materials and methods: Speech durations of Turkish orthopedists and the rates of these durations against the durations specified in the schedule were calculated. Any relationships between factors related to speakers who made presentations (age and place of work) and factors such as the day, auditorium, and hour of presentation with speech durations were investigated. Durations of sessions of sub-associations and branches were classified and statistically compared.

Results: Out of 480 speakers with a mean age of 47 years (range 28 to 71 years), only 171 (35.6\%) completed their presentations within the time specified in the schedule. Speech durations statistically significantly increased as the age of the speakers increased. Rates of non-compliance with time limit were higher in presentations performed on the first day. There was no significant difference between meeting auditoriums and meeting hours with regards to compliance with time limit percentages. An analysis based on places of work of speakers revealed no significant difference in terms of time usage percentages. A significant difference was present between the given and used times in the sessions of Society of Bone and Soft Tissue Tumors, Sports Traumatology Branch, and Turkish Society of Orthopaedics and Traumatology. Rates of compliance with time limit were higher in the sessions of Foot and Ankle Surgery Branch, Turkish Society of Shoulder and Elbow Surgery, and Turkish Society of Orthopaedic Research.

Conclusion: Turkish orthopedists are unsuccessful in complying with time limit in scientific presentations. Awareness should be raised on this subject and time discipline should be established with various measures and training.

Keywords: Compliance with time limit; national congress; orthopedics; scientific presentation.

\section{$\ddot{z z}$}

Amaç: Bu çalışmada ulusal olarak düzenlenen ve konuşmacı ve katılımcı sayıları açısından Türkiye'nin en büyük ortopedi ve travmatoloji toplantılarından olan 26. Ulusal Türk Ortopedi ve Travmatoloji Kongresinde bilimsel sunumların süreleri ve sunumlarda zaman kısıtlamasının aşılması oranlarına etki eden faktörler araştırıldı.

Gereç ve yöntemler: Türk ortopedistlerin konuşma süreleri ve bu sürelerin programda belirtilen sürelere oranları hesaplandı. Sunum yapan konuşmacılara ait etkenler (yaş ve çalıştıkları kurumlar) ve sunum yapılan gün, salon ve saat gibi etkenlerin konuşma süreleri ile ilişkisi olup olmadığı araştırıldı. Alt dernek ve şubelerin oturumlarındaki süreler sınıflandırılarak istatistiksel olarak karşılaştırıldı.

Bulgular: Yaş ortalaması 47 yıl (dağılım 28-71 yıl) olan 480 konuşmacının sadece 171 'i (\%35.6) sunumlarını programda belirtilen zaman içerisinde tamamladı. Konuşmacıların yaşı arttıkça konuşma süreleri istatistiksel olarak anlamlı şekilde arttı. Birinci gün yapılan sunumlarda zaman kısıtlamasına uymama oranları daha fazla idi. Toplantı salonları ve toplantı saatleri arasında zaman kısıtlamasına uyma yüzdeleri açısından anlamlı bir farklılık yoktu. Konuşmacıların çalıştığı kurumlara göre yapılan analiz, zamanı kullanma yüzdeleri açısından anlamlı bir farklılık göstermedi. Kemik Yumuşak Doku Tümörleri Derneği, Spor Travmatolojisi Şubesi ve Türk Ortopedi ve Travmatoloji Birliği Derneği oturumlarında verilen ve kullanılan zamanlar arasında anlamlı bir farklılık vardı. Ayak ve Ayak Bileği Cerrahisi Şubesi, Omuz Dirsek Cerrahisi Derneği ve Türk Ortopedik Araştırma Derneği oturumlarında zaman kisitlamasina uyma oranları daha yüksek idi.

Sonuç: Türk ortopedistleri bilimsel sunumlarda zaman kısıtlamasına uymada başarısızdır. Bu konuda farkındalık oluşturulmalı, çeşitli önlemler ve eğitimler ile zaman disiplini sağlanmalıdır.

Anahtar sözcükler: Zaman kısıtlamasına uyma; ulusal kongre; ortopedi; bilimsel sunum.

- Received: November 02, 2017 Accepted: November 07, 2017

- Correspondence: Nadir Yalçın, MD. Bağlıca Mah., 1088. Sok., Veranda Apt., No: 21/9, 06790 Etimesgut, Ankara, Turkey. Tel: +90 312 - 2912525 e-mail: drmnyalcin@yahoo.com 
Scientific meetings are highly important in academic society both for sharing knowledge, and social connections and associations. However, the increased number of scientific activities such as meetings, courses, congresses and symposiums in recent years causes gradual decrease in the interest and participation in these activities. In this context, the presenters should thoroughly understand what participants expect from this type of meetings and carefully examine the target audience to give the take-home message exactly on time. ${ }^{[1]}$ During the preparation of a scientific presentation, the information to be conveyed should be planned well and presented accordingly. The presenter should be able to express him/herself completely, gather the attention of the audience and make sure that what he/she presented is remembered..$^{[2-4]}$

Compared to meetings held abroad, time limits are much exceeded in meetings organized in Turkey since the moderators or chairmen do not show adequate sensitivity or do not intervene in time usage. Deviations in schedule are mostly experienced, and the participation rates substantially decrease due to time differences between auditoriums of meetings with multi-auditoriums.

Therefore, in this study, we aimed to investigate the durations of scientific presentations and factors affecting the rates of exceeding the time limit in presentations at $26^{\text {th }}$ Turkish National Congress of Orthopedics and Traumatology, which is one of Turkey's largest nationally organized orthopedics and traumatology meetings in terms of the numbers of speakers and participators.

\section{MATERIALS AND METHODS}

The study was conducted at Ankara Atatürk Training and Research Hospital between January 2017 and August 2017. Webcasts of videos recorded during $26^{\text {th }}$ Turkish National Congress of Orthopedics and Traumatology were examined and the durations between the beginning and ending of each presentation were calculated (http://webcastleri.com/2024-1-26_-ulusal-turkortopedi-ve-travmatoloji-kongresi-toplantilar.aspx). These durations were compared to the timetable specified in the schedule and percentages were obtained. The age and work place information of the presenters were acquired from internet and Turkish Society of Orthopedics and Traumatology (TSOT) registry. The data were classified based on the subassociations and branches as shown in congress schedule. The presentations of speakers who did not allow sharing of their speeches via webcast as well as foreign speakers and speakers who were not orthopedics and traumatology specialists were excluded. The study was conducted in accordance with the principles of the Declaration of Helsinki.

\section{Statistical analysis}

The concordance of the numerical variables to normal distribution was tested using KolmogorovSmirnov test. The categorical variables were described using frequency and percentage, while the numerical variables were described using median and minimum-maximum values. The relationship between the categorical variables was examined using chi-square test, and between the numerical variables using Spearman correlation analysis. The difference between the median values of two dependent samples was tested using Wilcoxon signed rank test. More than two independent median values were compared by Kruskal Wallis and post-hoc Dunn's test. The study was performed on 95\% confidence interval and $p$ values $<0.05$ were regarded as statistically significant.

\section{RESULTS}

The mean age of the speakers was 47 years (range 28 to 71 years). Only 171 speakers $(35.6 \%)$ completed their presentations within the time limit, and the remaining 309 speakers (64.4\%) exceeded their time limits in various degrees. When the presenters who exceeded the time limit at a minimum rate (accepted as $10 \%$ ) were added to the group who completed on time, these numbers were found to be 255 (53.1\%) and $225(46.9 \%)$, respectively. In other words, almost every second speaker exceeded the time limit in serious degrees (Tables I and II). When the speakers who exceeded their time limit at highest percentages were analyzed, it was seen that one speaker who had five-minute of talk time used 23.5 minutes without any intervention, and another one who also had five-minute of talk time used 22 minutes. The speaker

\section{TABLE I}

Number and percentage of presenters according to time usage

\begin{tabular}{lcc}
\hline Time usage & $\mathrm{n}$ & $\%$ \\
\hline On time & 171 & 35.6 \\
Exceeding $0.1 \%-10 \%$ & 84 & 17.5 \\
Exceeding $10.1 \%-20 \%$ & 74 & 15.4 \\
Exceeding $20.1 \%-30 \%$ & 57 & 11.9 \\
Exceeding $30.1 \%-50 \%$ & 50 & 10.4 \\
Exceeding $>50 \%$ & 44 & 9.2 \\
\hline
\end{tabular}


TABLE II

Detailed percentage of exceeding time according to day of congress, auditorium and hour of session

\begin{tabular}{|c|c|c|c|c|c|c|c|c|c|c|c|c|c|}
\hline & \multicolumn{2}{|c|}{$\begin{array}{l}\text { On time } \\
(n=171)\end{array}$} & \multicolumn{2}{|c|}{$\begin{array}{l}\text { Exceeding } \\
0.1 \%-10 \%\end{array}$} & \multicolumn{2}{|c|}{$\begin{array}{l}\text { Exceeding } \\
10.1 \%-20 \%\end{array}$} & \multicolumn{2}{|c|}{$\begin{array}{l}\text { Exceeding } \\
20.1 \%-30 \%\end{array}$} & \multicolumn{2}{|c|}{$\begin{array}{l}\text { Exceeding } \\
30.1 \%-50 \%\end{array}$} & \multicolumn{2}{|c|}{$\begin{array}{c}\text { Exceeding } \\
>\% 50\end{array}$} & \multirow[b]{2}{*}{$p$} \\
\hline & $n$ & $\%$ & $\mathrm{n}$ & $\%$ & $\mathrm{n}$ & $\%$ & $\mathrm{n}$ & $\%$ & $n$ & $\%$ & $\mathrm{n}$ & $\%$ & \\
\hline Day & & & & & & & & & & & & & $0.017^{*}$ \\
\hline 1 & 36 & 21.1 & 19 & 22.6 & 16 & 21.6 & 16 & 28.1 & 20 & 40.0 & 17 & 38.6 & \\
\hline 2 & 42 & 24.6 & 20 & 23.8 & 23 & 31.1 & 20 & 35.1 & 7 & 14.0 & 9 & 20.5 & \\
\hline 3 & 43 & 25.1 & 22 & 26.2 & 16 & 21.6 & 10 & 17.5 & 15 & 30.0 & 15 & 34.1 & \\
\hline 4 & 50 & 29.2 & 23 & 27.4 & 19 & 25.7 & 11 & 19.3 & 8 & 16.0 & 3 & 6.8 & \\
\hline Auditorium & & & & & & & & & & & & & 0.128 \\
\hline 1 & 21 & 12.3 & 7 & 8.3 & 14 & 18.9 & 10 & 17.5 & 3 & 6.0 & 7 & 15.9 & \\
\hline 2 & 32 & 18.7 & 16 & 19.0 & 8 & 10.8 & 9 & 15.8 & 9 & 18.0 & 3 & 6.8 & \\
\hline 3 & 28 & 16.4 & 10 & 11.9 & 19 & 25.7 & 10 & 17.5 & 7 & 14.0 & 11 & 25.0 & \\
\hline 4 & 31 & 18.1 & 22 & 26.2 & 12 & 16.2 & 12 & 21.1 & 8 & 16.0 & 9 & 20.5 & \\
\hline 5 & 31 & 18.1 & 14 & 16.7 & 10 & 13.5 & 10 & 17.5 & 18 & 36.0 & 10 & 22.7 & \\
\hline 6 & 28 & 16.4 & 15 & 17.9 & 11 & 14.9 & 6 & 10.5 & 5 & 10.0 & 4 & 9.1 & \\
\hline Hour of session & & & & & & & & & & & & & 0.741 \\
\hline 08:00-09:15 & 29 & 17.0 & 14 & 16.7 & 14 & 18.9 & 9 & 15.8 & 11 & 22.0 & 7 & 15.9 & \\
\hline 09:30-10:45 & 27 & 15.8 & 16 & 19.0 & 14 & 18.9 & 18 & 31.6 & 6 & 12.0 & 6 & 13.6 & \\
\hline $11: 15-12: 30$ & 32 & 18.7 & 13 & 15.5 & 9 & 12.2 & 9 & 15.8 & 7 & 14.0 & 10 & 22.7 & \\
\hline $14: 00-15: 15$ & 32 & 18.7 & 13 & 15.5 & 18 & 24.3 & 9 & 15.8 & 12 & 24.0 & 5 & 11.4 & \\
\hline $15: 45-17: 00$ & 27 & 15.8 & 14 & 16.7 & 10 & 13.5 & 5 & 8.8 & 5 & 10.0 & 9 & 20.5 & \\
\hline $17: 15-18: 30$ & 24 & 14.0 & 14 & 16.7 & 9 & 12.2 & 7 & 12.3 & 9 & 18.0 & 7 & 15.9 & \\
\hline
\end{tabular}

* The difference between days was more significant between on time and exceeding $50 \%$.

who had the longest talk time of 37 minutes was given only 15 minutes.

When the correlation between the used time and age was examined, a statistically significant linear relationship was found. In other words, the durations and the percentages of exceeding the time limit increased with the speaker's increasing age (Table III).

When the days of the presentation were compared to the percentage of time use, a statistically significant difference was detected between the first and fourth days. Rate of non-compliance with time limit was higher in the presentations performed on the first day. Time compliance was higher in the last day of the congress. No significant difference was found between meeting auditoriums and meeting hours with regards to time compliance percentage. Nevertheless, when the sessions of different subassociations and branches were examined, a statistically significant difference was detected. This difference was more pronounced between Bone and Joint Surgery Society - Sports Traumatology Branch and Bone and Joint Surgery - Society of Bone and Soft Tissue Tumors (Table IV).
When the speakers were analyzed based on their work place, no significant difference was found with regards to time use percentage. While the majority of the speakers worked in training clinics $(80.9 \%)$, no significant difference in time compliance was found between them and the physicians working in public hospitals, private hospitals or private clinics. Noncompliance with time limits in various degrees was detected in all work places (Table IV).

An examination on whether there was a statistically significant difference between the given time and used time on different days of the congress revealed a significant difference in time limit exceeding for the first, second and third days $(\mathrm{p}<0.001)$. When sessions

\section{TABLE III}

Correlation of age with time used and proportion of time used to given time

\begin{tabular}{lcc}
\hline & \multicolumn{2}{c}{ Age } \\
\cline { 2 - 3 } & $r$ & $p$ \\
\hline Time used (sec) & 0.146 & 0.001 \\
Percent of time used to given time & 0.121 & 0.008 \\
\hline
\end{tabular}


TABLE IV

Significance between proportions of time used to given time and day of congress, auditorium, hour of session, sessions of sub-associations and branches and work places of presenters

\begin{tabular}{|c|c|c|c|c|c|c|}
\hline \multirow{3}{*}{ Day } & \multirow[b]{2}{*}{$\mathrm{n}$} & \multicolumn{5}{|c|}{ Percent of time used to given time } \\
\hline & & $\%$ & Median & Min- & Max & $p$ \\
\hline & & & & & & \\
\hline 1 & 124 & 25.8 & 14.1 & -62.7 & -117.7 & \\
\hline 2 & 121 & 25.2 & 7.6 & -48.2 & -85.1 & \\
\hline 3 & 121 & 25.2 & 7.5 & -43.8 & -370 & \\
\hline 4 & 114 & 23.8 & 3.1 & -58.8 & -93.3 & \\
\hline Auditorium & & & & & & 0.057 \\
\hline 1 & 62 & 12.9 & 11.3 & -43.8 & -90.2 & \\
\hline 2 & 77 & 16 & 3.3 & -62.7 & -117.7 & \\
\hline 3 & 85 & 17.7 & 11.8 & -38.6 & -152 & \\
\hline 4 & 94 & 19.6 & 6.4 & -39.2 & -370 & \\
\hline 5 & 93 & 19.4 & 10.8 & -44.2 & -82.5 & \\
\hline 6 & 69 & 14.4 & 4.2 & -58.8 & -74.5 & \\
\hline \multicolumn{7}{|l|}{ Hour of session } \\
\hline 08:00-09:15 & 84 & 17.5 & 8.5 & -49.2 & -108.8 & 0.926 \\
\hline $09: 30-10: 45$ & 87 & 18.1 & 10.1 & -34.9 & -146.7 & \\
\hline $11: 15-12: 30$ & 80 & 16.7 & 4.9 & -44.2 & -370 & \\
\hline $14: 00-15: 15$ & 89 & 18.5 & 9.8 & -46.9 & -74.5 & \\
\hline $15: 45-17: 00$ & 70 & 14.6 & 4.0 & -62.7 & -100.2 & \\
\hline 17:15-18:30 & 70 & 14.6 & 6.5 & -39.2 & -152 & \\
\hline Sessions of Sub-associations \& Branches & & & & & & $0.003^{t, \neq}$ \\
\hline Society of Foot and Ankle & 31 & 6.5 & 8.9 & -49.2 & -146.7 & \\
\hline Society of Pediatric Orthopaedics & 30 & 6.3 & 7.3 & -38 & -69.5 & \\
\hline $\begin{array}{l}\text { Association for the Study and Application of the } \\
\text { Method of llizarov External Fixation }\end{array}$ & 11 & 2.3 & -3.0 & -18.9 & -45.8 & \\
\hline Turkish Hand Surgery Society & 34 & 7.1 & 8.3 & -48.2 & -65.8 & \\
\hline Hip and Knee Arthroplasty Society & 39 & 8.1 & 11.7 & -41.3 & -100.2 & \\
\hline Bone and Joint Surgery Society & 14 & 2.9 & -9.2 & -38.9 & -38.1 & \\
\hline Society of Bone and Soft Tissue Tumors & 36 & 7.5 & 17.3 & -35.6 & -152 & \\
\hline Turkish Society of Shoulder and Elbow Surgery & 24 & 5 & 0.2 & -34.9 & -27.9 & \\
\hline Turkish Spine Society & 31 & 6.5 & 4.9 & -58.8 & -74.5 & \\
\hline Sports Traumatology & 33 & 6.9 & 16.5 & -24.6 & -82.5 & \\
\hline Turkish Society of Orthopaedic Research & 8 & 1.7 & -0.1 & -46.9 & -17.9 & \\
\hline Turkish Society of Orthopaedics and Traumatology & 136 & 28.3 & 10.6 & -44.2 & -370 & \\
\hline Turkish Association of Orthopaedics and Traumatology & 26 & 5.4 & 3.4 & -62.7 & -93.3 & \\
\hline Trauma Society & 27 & 5.6 & 5.3 & -19 & -70.9 & \\
\hline Presenters work place & & & & & & 0.122 \\
\hline Public University & 201 & 41.9 & 7.5 & -62.7 & -146.7 & \\
\hline Private University & 69 & 14.4 & 10.1 & -52.4 & -108.8 & \\
\hline Training and Research Hospital & 118 & 24.6 & 4.9 & -49.2 & -370 & \\
\hline Public Hospital & 4 & 0.8 & -9.4 & -38.9 & -0.9 & \\
\hline Private Hospital & 73 & 15.2 & 10.8 & -38.6 & -342.3 & \\
\hline Private Office & 15 & 3.1 & 16.4 & -10.7 & -86.7 & \\
\hline
\end{tabular}

Min: Minimum; Max: Maximum; ${ }^{\text {st }}$ sth $^{\text {th }}$ day; † Bone and Joint Surgery Society-Sports Traumatology; $\ddagger$ Bone and Joint Surgery Society-Sports Traumatology-Society of Bone and Soft Tissue Tumors. 
TABLE V

Comparison of given time and time used in terms of day of congress and sessions of sub-associations and branches

\begin{tabular}{|c|c|c|c|c|c|}
\hline & \multicolumn{2}{|c|}{ Given time (sec) } & \multicolumn{2}{|c|}{ Time used (sec) } & \multirow[b]{2}{*}{$p$} \\
\hline & Median & Min-Max & Median & Min-Max & \\
\hline \multicolumn{6}{|l|}{ Day } \\
\hline 1 & 720 & $300-1800$ & 759 & $268-1920$ & $<0.001$ \\
\hline 2 & 720 & $480-1200$ & 783 & $352-2051$ & $<0.001$ \\
\hline 3 & 720 & $300-2700$ & 794 & $370-2255$ & 0.001 \\
\hline 4 & 600 & $480-1200$ & 671 & $297-1290$ & 0.668 \\
\hline \multicolumn{6}{|l|}{ Sessions of Sub-associations \& Branches } \\
\hline Society of Foot and Ankle & 900 & $600-1500$ & 898 & $457-2220$ & 0.203 \\
\hline Society of Pediatric Orthopaedics & 720 & $600-1200$ & 802.5 & $579-1449$ & 0.075 \\
\hline $\begin{array}{l}\text { Association for the Study and Application of the } \\
\text { Method of llizarov External Fixation }\end{array}$ & 780 & $780-780$ & 757 & $633-1137$ & 0.790 \\
\hline Turkish Hand Surgery Society & 900 & $600-1200$ & 901 & $373-1721$ & 0.297 \\
\hline Hip and Knee Arthroplasty Society & 600 & $600-600$ & 670 & $352-1201$ & 0.017 \\
\hline Bone and Joint Surgery Society & 900 & $720-2700$ & 894 & $462-2255$ & 0.149 \\
\hline Society of Bone and Soft Tissue Tumors & 720 & $420-900$ & 745.5 & $464-1666$ & $<0.001$ \\
\hline Turkish Society of Shoulder and Elbow Surgery & 900 & $900-900$ & 897 & $586-1151$ & $>0.999$ \\
\hline Turkish Spine Society & 720 & $600-1200$ & 745 & $297-1152$ & 0.389 \\
\hline Sports Traumatology & 480 & $480-900$ & 653 & $370-1023$ & 0.001 \\
\hline Turkish Society of Orthopaedic Research & 900 & $900-900$ & 899.5 & $478-1061$ & 0.484 \\
\hline Turkish Society of Orthopedics and Traumatology & 720 & $300-900$ & 754 & $268-1503$ & $<0.001$ \\
\hline Turkish Association of Orthopaedics and Traumatology & 600 & $540-1800$ & 613 & $442-1160$ & 0.228 \\
\hline Trauma Society & 720 & $480-1200$ & 712 & $532-2051$ & 0.049 \\
\hline
\end{tabular}

Min: Minimum; Max: Maximum.

of sub-associations and branches were examined individually, a significant difference was found between given and used times particularly in the sessions of Society of Bone and Soft Tissue Tumors, ST Branch, and TSOT. The sessions of Foot and Ankle Surgery Branch, Turkish Society of Shoulder and Elbow Surgery, and Turkish Society of Orthopaedic Research had higher time compliance rates (Table V).

\section{DISCUSSION}

In this study, we examined the compliance of orthopedic surgeons who made presentations during the $26^{\text {th }}$ Turkish National Congress of Orthopedics and Traumatology with the given time limits. Unfortunately, we demonstrated that the orthopedic surgeons considerably exceeded their given time and were unsuccessful in complying with the time limit.

Although presentations should be completed within the recommended time period, noncompliance with the time limit is a common mistake during presentations. The extension of time may cause distraction in the audience for the next speaker. ${ }^{[2]}$ According to the literature, the audience gets bored when the talk time exceeds 20 minutes. ${ }^{[4,5]}$ Speaking very fast or very slow also makes the presentation incomprehensible and boring. The speaking pace should be slow enough to facilitate understanding and fast enough to avoid distraction. The presenter should be able to clearly give the message that he/ she wants to convey to the audience at his/her usual speaking pace. ${ }^{[5,6]}$ The inclusion of every piece of information, which the presenter found interesting or important, into the presentation will make all the information mediocre for the audience. In this phenomenon known as presenter's paradox, the important information loses its value and the desired effect decreases. All information, which is not significant for the audience, should be removed from the presentation. ${ }^{[6]}$

In addition to the extending presentation times; we frequently encounter technical problems such as failure to project the presentation onto the screen, to play videos, or incompatibility issues due to differences between operating systems, etc. Moreover, sessions may start later then the given beginning time while the question \& answer discussions may exceed the anticipated time limit. Due to all above mentioned reasons, unfortunately, almost all sessions 
exceed the planned time limits, causing a delay in the next session whilst hindering participants from participating in sessions in other auditoriums, and overall resulting in disruption in the schedule. This may lead to gradual decrease in the number of audience throughout the meeting.

A correlation was found between the increased age of the presenter and increased presentation time. In other words, the compliance with time limits decreases with the presenter's increasing age. This might be because of relatively more experienced presenters wanting to share and reflect their experiences more, and also, using their previously prepared presentations without any worry of shortening them to make them time-compliant. The fact that we detected no difference between presenters working in training clinics and those working in public hospitals or the private sector is another striking result of this study. It was surprising that trainers, who provided training, made regular presentations, and were expected to be more experienced in terms of presentation techniques, used equal durations with their colleagues who were not trainers.

Furthermore, the difference between the given and used times on the first three days of the congress was found to be statistically significant. Same difference could not be detected on the last day of the congress. This might be because of participants and presenters wanting to use their time efficiently due to their return preparations on the last day. An examination between meeting auditoriums and presentation hours showed no difference with regards to compliance with time limits.

Also, we observed that exceeding time limits during speeches were usually not intervened. The attitude of the chairman to the presenter varied as follows:

1. Passive attitude: Does not intervene in the presenter, he/she waits till the end of the presentation.

2. Proactive attitude: Warns the presenters at the beginning of the session to comply with the time limit. However, this warning does not affect the durations since the presentations were prepared previously.

3. Active attitude: Warns the presenter when the exceeding period surpasses certain duration, and if necessary, warns a second time.

The attitude of the presenter to exceeding time or the warning of the chairman also varied as following:
1. Passive attitude: Ignores the warning completely, keeps up with the same pace until the presentation is completed as he/she previously prepared.

2. Flurry attitude: Takes the warning into consideration; however, as he/she is trying to perform the presentation faster, completes the presentation by skipping the slides or talking fast. Take-home messages or matters to remember usually cannot be conveyed to the audience.

3. Aggressive attitude: Thinks like "I was doing very well, why did the chairman interrupt me?" Usually does not care for the time limit. He/she shows that he/she is angry. Either continues with the passive attitude or immediately ends the speech. Either way, the message cannot be conveyed completely to the audience.

Clear instructions should be given both to chairmen and presenters before meetings about complying with time limits as a standard procedure, its importance, and what to do during presentations. These warnings should be repeated continuously until this discipline is obtained. Orthopedists, at any time, need to remember not only being a surgeon but also being a physician and a good presenter. ${ }^{[7]}$

A limitation of this study was the evaluation of the durations of presentations only. Other factors including technical problems, delayed beginning, or long-lasting discussions that may cause extension of the total durations of sessions could not be evaluated due to technical reasons.

In conclusion, in this study, we aimed to raise awareness on the importance of compliance with time limits among Turkish orthopedists and providing scientific and satisfactory content in presentations without causing distraction in audience; therefore, increasing participation in sessions. To establish this discipline, it might be reasonable to organize training programs including presentation skills, send repetitive warning messages about time-compliance before meetings, place stopwatches on suitable places, and give the required authorization to chairmen to intervene in the speakers as needed.

\section{Declaration of conflicting interests}

The authors declared no conflicts of interest with respect to the authorship and/or publication of this article.

\section{Funding}

The authors received no financial support for the research and/or authorship of this article. 


\section{REFERENCES}

1. Available from: http://www.consultantsmind. com/2012/04/30/ppt/

2. Duarte N. Slide:ology: The Art and Science of Creating Great Presentations. 1st ed. California: O’Reilly Media 2008. p. 251-62.

3. Duarte N. Resonate: Present Visual Stories that Transform Audiences. New Jersey: John Wiley \& Sons; 2013. p. 1-44.

4. Available from: https://hbr.org/2012/10/create- presentations-an-audien

5. Available from: http://www.washington.edu/doit/ presentation-tips-0

6. Tübitak Bilimsel Araştırmalar. Etkili sunumlar için el kitabı. Ankara: Tübitak, 2013. s. 1-34. Available from: http://www. tubitak.gov.tr/sites/default/files/content_files/iletisim/ sunum_el_kibabi.pdf

7. Atik OŞ. Do we surgeons perform surgery only? Eklem Hastalik Cerrahisi 2016;27:123-4. 